\title{
EFEKTIFITAS TERAPI SPIRITUAL WUDHU UNTUK MENGONTROL EMOSI PADA PASIEN RESIKO PERILAKU KEKERASAN
}

\section{EFFECTIVENESS OF SPIRITUAL THERAPY FOR ABLUTION TO CONTROL EMOTION IN PATIENT WITH VIOLENT BEHAVIOR IN SURAKARTA'S PSYCHIATRIC HOSPITAL}

\author{
Ika Kusuma Wardhani1, Anis Prabowo2, Grahita Bara Brilianti3 \\ Program Studi Keperawatan, Fakultas Kesehatan \\ ITS PKU Muhammadiyah Surakarta \\ e-mail: $\underline{\text { ikakusuma89@itspku.ac.id }}$
}

INFO

\section{ARTIKEL}

Kata Kunci :

Anemia, asupan protein, pola makan, ibu hamil trimester III, zat besi.

Key Word : Anemia, protein intake, eating pattern, third trimester pregnant woman, ferrum.

\begin{abstract}
ABSTRAK/ABSTRACT
Perilaku kekerasan adalah suatu penyakit yang mempengaruhi otak dan menyebabkan timbulnya pikiran, persepsi, emosi, gerakan, perilaku yang aneh dan terganggu. Dalam penanganan pasien dengan masalah risiko perilaku kekerasan dapat dilakukan dengan kombinasi psikofarmakologi dan intervensi psikososial seperti okupasi, terapi keluarga, dan terapi psikoterapi yang menampakkan hasil yang lebih baik. Diketahui terapi spiritual wudhu memiliki efek relaksasi bagi tubuh, sehingga mampu merangsang pengeluaran hormon endorphin dalam tubuh dan menekan hormon adrenalin. Karena wudhu merupakan obat dari Allah berupa dzikrullah sebagaimana disebutkan dalam hadist "sesungguhnya amarah itu dari setan dan setan terbuat dari api. Api akan padam dengan air. Apabila salah seorang dari kalian marah, hendaknya berwudhu" (HR. Abu Daud). Metode Penelitian : metode dalam studi kasus ini menggunakan metode pengumpulan data melalui observasi, wawancara, dan dokumentasi yang meliputi data primer data sekunder serta ditambah menggunakan instrumen studi kasus yang meliputi : pengkajian, diagnosa, intervensi, implementasi, dan evaluasi yang dilakukan pada 2 klien yang mengalami resiko perilaku kekerasan, beragama islam dilakukan selama 6 kali pertemuan. Hasil penelitian ini adalah setelah dilakukan tindakan keperawatan selama 6 hari klien mampu mengontrol perilaku kekerasan dan pasien menjadi lebih tenang.

Violent behavior, spiritual ablutio, calmness. Violent behavior is a disease that affects the brain and causes thoughts, perceptions, emotions, movements, strange and disturbed behavior. In handling patients with risk problems of violent behavior can be done with a combination of psychopharmacology and psychosocial interventions such as occupation, family therapy, and psychotherapy therapy which shows better results. It is known that ablution spiritual therapy has a relaxing effect on the body, so that it can stimulate the expenditure of endorphin hormones in the body and suppresses the hormone adrenaline. Because ablution is a medicine from Allah in the form of dhikrullah as mentioned in the hadith "actually anger is from
\end{abstract}


Methods: the method in this case study uses the method of collecting data through observation, interviews, and documentation that includes primary data secondary data and supplemented using case study instruments which include: assessment, diagnosis, intervention, implementation, and evaluation conducted on 2 clients who run the risk of violent behavior, Islam is held for 6 meetings. The results of this study are that after nursing action is carried out for 6 days the client is able to control violent behavior and the patient becomes calmer.

\section{A. PENDAHULUAN}

Perilaku kekerasan adalah suatu keadaan dimana seseorang melakukan tindakan yang dapat membahayakan secara fisik baik diri sendiri maupun orang lain, dan lingkungan yang merupakan respon dari kecemasan dan kebutuhan yang tidak terpenuhi yang dirasakan sebagai ancaman disertai dengan amuk dan gaduh gelisah yan tidak terkontrol (Wijayaningsih, 2015).

Menurut data WHO pada tahun 2012 angka pendrita gangguan jiwa mengkhawatirkan secara global, sekitar 450 juta orang yang menderita gangguan mental. Orang yang mengalami gangguan jiwa sepertiganya tinggal di negara berkembang, sebanyak 8 dari 10 penderita gangguan mental itu tidak mendapatkan perawatan (Kemenkes RI, 2014).

Menurut data WHO (2016), terdapat sekitar 35 juta orang terkena depresi, 60 juta orang terkena bipolar, 21 juta terkena skizofrenia, serta 47,5 juta terkena dimensia. Di Indonesia pada tahun 2013 menunjukkan bahwa jumlah prevalensi gangguan jiwa berat nasional adalah sebesar 1,7 permil. Prevalensi psikosis di Jawa Tengah sebesar $(2,3 \%)$ dan untuk prevalensi gangguan mental emosional di Jawa Tengah sebesar (4,7\%), (Riskesdas). Di RSJD dr. Arif Zainudin Surakarta, , ditemukan masalah keperawatan pada pasien rawat inap dan rawat jalan yaitu halusinasi

4.021 kasus, resiko perilaku kekerasan 3.980 kasus, defisit perawatan diri 1.754 kasus, isolasi sosial 1.871 kasus, harga diri rendah

1.026 kasus, dan waham 401 kasus (Rekam Medik, 2019).

Faktor risiko yang dapat ditimbulkan oleh pasien yang mengalami perilaku kekerasan adalah dapat membahayakan diri sendiri dan orang lain, Untuk memperkecil dampak yang ditimbulkan, dibutuhkan penanganan risiko perilaku kekerasan yang tepat (Wijayaningsih, 2012). Penanganan pasien dengan resiko perilaku kekerasan dapat dilakukan dengan farmakologi dan strategi pelaksanaan pada pasien resiko perilaku kekerasan, tindakan keperawatan pada pasien resiko perilaku kekerasan difokuskan pada aspek positif, intelektual, emosional, dan sosio spiritual. Salah satunya dalah dengan terapi spiritual wudhu (Dalami, 2010).

Berdasarkan penelitian oleh Purnamasari dan Rakhman (2015) diperoleh kesimpulan ada pengaruh spiritual wudhu terhadap perubahan status mental klien resiko perilaku kekerasan. Karena wudhu bermanfaat untuk menjernihkan pikiran, menyejukkan hati, mengurangi stress, rasa khawatir, marah, merangsang dan mengefektifkan sistem kereja saraf. Wudhu termasuk psikoterapi islami dengan menggunakan media air, Dalam sejarahnya, air juga pernah digunakan oleh Rasulullah saw untuk pengobatan. Saat itu Rasulullah saw berdo'a dan memercikan ke tubuh orang yang sakit (Bentanie, 2010).

Spiritual adalah keyakinan dalam hubunganya dengan yang maha kausa dan pencipta. Sebagai contoh seseorang yang

percaya kepada Allah sebagai pencipta atau sebagai maha kuasa (Hamid, 2009). Wudhu merupakan mengguanakan air untuk anggota- anggota tubuh tertentu (wajah, dua tangan, kepala, dua kaki) (Bentanie, 2010). Aktivitas yang dilakukan oleh orang untuk mensucikan diri dari hadast dan cara membersihkan nasjis kecil dengan menggunakan air yang dilakukan dalam agama islam sebelum melakukan sholat (Matheer, 2014). Dan apabila ada keinginan marah muncul hendaknya berwudhu sebagaimana hadist yang telah diriwayatkan Athiyyah as-sa'di Radhiyaallahu anhu berkata:

\section{B. METODE}

Metode penelitian ini menggunakan metode studi kasus didapatkan berjumlah 2 orang pasien yang mengalami resiko perilaku kekerasan dengan kriteria hasil pasien beragama islam dan mengalami resiko perilaku kekerasan, penelitian dilakukan selama 6 hari , mulai tanggal 9 Maret - 14 Maret 2020. Tempat penelitian di RSJD dr. Arif Zainudin Surakarta. Instrumen penelitian 
yang digunakan antara lain formal asuhan keperawatan jiwa, buku panduan, NANDA, NOC dan NIC, alat tulis, lembar observasi, SOP wudhu.

\section{HASIL DAN PEMBAHASAN}

Hasil pengkajian yang dilakukan dari 2 pasien didapatkan keluhan sering marah, mudah tersinggung. Berdasarkan analisa data maka diagnosa yang tepat adalah resiko perilaku kekerasan. Implementasi yang dilakukan kepada 2 pasien tersebuat adalah SP 4 yaitu spiritual wudhu yang bertujuan untuk mengontrol emosi. Implementasi hari pertama adalah mengajarkan SP 1 yaitu menjelaskan tanda dan gejala, akibat, penyebab, keuntungan dan kerugian dari perilaku kekerasan, latihan mengontrol emosi dengan nafas dalam dan pukul bantal, anjurkan pasien untuk mempraktekan sendiri, kemudian ajarkan SP 2 yaitu minum obat dengan baik dan benar, masukkan dalam jadwal kegiatan harian. kontrak waktu untuk latihan SP 3 selanjutnya. Implementasi hari ke-2 yaitu evaluasi SP 1 dan 2 yaitu nafas dalam dan pukul bantal, minum obat kemudian memberi pasien pujian, kemudian ajarkan SP 3 yaitu latihan cara mengontrol emosi dengan cara verbal. Masukkan kedalam jadwal harian untuk latihan fiki, minum obat dan cara verbal. Kontrak waktu untuk kegiatan berikutnya yaitu latiahn SP 4. Implementasi hari ke 3 yaitu evaluasi cara mengontrol emosi dengan cara fisik, minum obat, cara verbal. Kemudian latih cara mengontrol emosi dengan SP 4yaitu dengan cara spiritual wudhu. Masukkan kedalam jadwal harian untuk latihan fiski, minum

obat, cara verbal, dan spiritual wudhu. Implementasi hari ke 4 yaitu evaluasi cara mengontrol emosi dengan cara fisik, minum obat dan cara verbal, ajarakan SP 4 yaitu spiritual wudhu, pasien belum mampu mengontrol emosinya, masih mudah marah- marah dengan temannya, wudhu masih terbolak balik skor Tn. F:3 skor Tn. S:3. Implementasi hari ke 5 Pasien belum mampu mengontrol emosi, emosi pasien masih labil, tatpan mata masih tajam skor Tn. F:2 skor Tn S:2.
Implementasi hari ke 6, klien mampu mengontrol emosi, mampu mempraktekkan wudhu saat stimulus marah mucul. Skor Tn. F:1 skor Tn.S:1.

Berdasarkan penelitian yang telah dilakukan Purnamasari dan Rakhman (2015) dengan pemberian terapi spiritual wudhu menunjukkan bahwa terapi spiritual dapat mengontrol emosi pada pasien resiko perilaku kekerasan. Dilakukan intervensi keperawatan selama 6 kali pertemuan terjadimpenurunan emosi pada pasien resiko perilaku kekerasan.

\section{KESIMPULAN DAN SARAN}

Dari pembahasan mengenai makna wudhu bagi pasien di RSJD Surakarta pada pasien Resiko Perilaku Kekerasan dengan melihat proses pasien berwudhu, maka diperoleh kesimpulan bahwa dengan berwudhu sesuai dengan tuntunan yang diajarkan oleh Rasulullah Saw dan menghayati setiap basuhan dan gerakangerakan wudhu serta adanya motivasi dari dalam diri untuk tetap mempertahankan wudhu sehingga membuat semua subjek mampu mengatasi hambatan dan tantangan.

Selain itu melalui proses pembiasaan selama 6 hari membiasakan berwudhu, pasien dapat merasakan manfaat wudhu bagi fisik maupun psikis karena wudhu yang dimaknai pasien sebagai adanya perasaan nyaman, damai, tenteram, bahagia karena dapat terjaga dan terhindar dari hal-hal yang negatif, terhindar dari amarah yang berlebihan, adanya perasaan tenang karena mendapat kemudahan untuk beribadah setiap saat.

Ketenangan itu berupa ketenangan pada aspek kognitif, afektif dan spiritual pasien.

\section{DAFTAR PUSTAKA}

Adhyatma, Pidato Pembukaan Kongres Ilmiah Ikatan Sarjana Farmasi Indonesia, 2 Mei 1991.

Baroroh, H.N., Warsinah, dan Harwoko, 2012, Aktivitas Fraksi Protein Jatropa curcas Sebagai Antikanker terhadap 
Ekspresi p53 pada Kulit Mencit Pasca Pemaparan DMBA dan UVB, Jurnal Ilmu Kefarmasian Indonesia, 10 (2): 138-143.

Benowitz, N.L., 2001, Obat Antihipertensi, dalam Katzung, B.G., Basic and Clinical Pharmacology, 8th edt., diterjemahkan oleh Bagian Farmakologi Fakultas Kedokteran Universitas Airlangga, Salemba Medika, Jakarta, 269-304.

Cannell, R.J.P., 1998, Natural Product Isolation, Humana Press, Totowa, 290-291.

Depkes R.I., 1979, Farmakope Indonesia, Edisi III, Departemen Kesehatan Republik Indonesia, Jakarta, 109-115.

Gusyana, D., 2008, Milk thistle (Silybum marianum) Tanaman Kesehatan Obat Kanker, http://www.ubb.ac.id, diakses 1 Juli 2010.

Harborne, J.B., 1987, Metode Fitokimia, Penuntun Cara Modern Mengekstraksi Tumbuhan, diterjemahkan oleh K. Padmawinata, Penerbit ITB, Bandung, 147-155.

Kemenkes R.I.a, 2014, Permenkes Nomor 35 Tentang Standar Pelayanan Kefarmasian di Apotek, Kementerian Kesehatan Republik Indonesia, Jakarta.

Kurniawan, D.W. dan Utami, V.V.F.R, 2012, Formulasi dan Evaluasi Mikropartikel Mukoadesif Metformin Hidroklorida Menggunakan Matriks Pautan Silang Kitosan-Natrium Alginat, Laporan Hasil Penelitian, LPPM Universitas Jenderal Soedirman, Purwokerto.

Martono, S., 1996, Penentuan kadar kurkumin secara kromatografi lapis tipisdensitometri, dalam Buletin ISFI Yogyakarta, II, 4, Yogyakarta.

Nuryanti, 1995, Efek Antihepatotoksik Infus Batang Brotowali (Tinospora crispa Linn.) pada Tikus yang diberi Karbon Tetraklorida, Skripsi, Jurusan Farmasi Universitas Indonesia, Jakarta.

Purcell, W.P., Bass, G.E., dan Clayton, J.M., 1967, Strategy of Drug Design: A Guide to Biological Activity, John Wiley and Sons, New York, 89-94.

Sari, A., Wahyono, D., dan Raharjo, B., 2011, Pengaruh Pelayanan Informasi Obat Terhadap Potensi Interaksi Obat pada Pasien Rawat Inap Penyakit Dalam di RSUD Prof. Dr. Margono Soekarjo Purwokerto Periode MaretAgustus 2010, Prosiding Seminar Nasional "Eight Star Performance Pharmacist", Program Pascasarjana Ilmu Farmasi UGM, Yogyakarta, 1-7 
